\title{
Palackého federalismus a jeho koaliční potenciál
}

\section{Palacký's federalism and its potential for coalitions}

\author{
Jiří Štaif / staif@cmail.cz \\ Ústav hospodářských a sociálních dějin, Filozofická fakulta, Univerzita Karlova, Praha, CZ
}

\begin{abstract}
The federalism of František Palacký (1798-1876) was firstly influenced by statistical data on the population numbers of the individual nations and nationalities within the Habsburg monarchy. There was also the concept of Austro-Slavism, which emphasized the cultural, demographic and economic importance of the Slavs living in this state. During the revolution of 1848-1849, he linked this with an Austro-federalism, though he failed to acquire sufficient political support. This was also the case after 1860 when the Czech politician tried in vain to win the support of France and Russia. At this point it was obvious that his Austro-federalism lacked the sufficient coalition potential to succeed.
\end{abstract}

\section{Keywords}

František Palacký, Austroslavism, Austrofederalism, coalition potential 
V české historiografii je zvykem nahlížet na Palackého federalismus jako na něco samozřejmého. Poměrně obtížná je však odpověd’ na otázku, jak vlastně k tomuto nejen politickému, nýbrž i kulturnímu konceptu dospěl. Pořadí obou pojmů by však mělo být vlastně obrácené, nebot se domnívám, že to, co bychom mohli označit pojmem federalismus, pro něj mělo nejdříve kulturní význam a až později nabylo na významu politickém. Pod pojmem federalismus si představuji snahy o sdružování jednotlivých částí, at již mají podobu historicky nebo nově vzniklých územních jednotek, kultur, národů nebo jinou ve společné celky, usilující o to, aby nabyly na větším významu, jehož by jako takové mohly jen obtížně dosáhnout. Jejich reprezentanti přitom očekávají, že tak pro ně získají kýžené jistoty svébytné existence, kterou by v daném mocenském kontextu či jinak chápané konkurenci nebyly schopny uhájit. Nezřídka jsou přitom postaveni před otázku, jak čelit vnějšímu tlaku, který vnímají jako ohrožení, bez něhož by k takovému sdružování nemuselo vůbec docházet. Pokud však pomíjí, pak jsou federalistické celky obvykle problematizovány, a to zejména v těch případech, když mezitím nevzniknou mezi jejich částmi pevnější vnitřní vazby.

Jako mladík, jenž se zajímal o veřejné dění, byl František Palacký dobře informován o zásadách, na nichž vznikal Německý spolek (1815). Nezdá se však, že by pro něj byl tento způsob uspořádání střední Evropy, jenž se ji snažil po napoleonských válkách politicky stabilizovat na protirevolučních zásadách vnitřní politiky a územní nedotknutelnosti, př́iliš inspirativní pro utváření jeho představ o tom, jak má federativní stát vypadat. Zjevné je však to, že zavedení politického systému konstitučních monarchií, k němuž došlo v některých státech tohoto spolku, začal již r. 1819 považovat z hlediska zájmů českých obrozenců za předčasné, ačkoliv moderní konstitucionalismus jako takový obdivoval. Byl si totiž velmi dobře vědom toho, že by se jejich nepočetní představitelé v případném parlamentu jen obtížně prosazovali vedle reprezentantů majetnějších a vzdělanějších německojazyčných středních vrstev, kteří by moderní liberalismus podle jeho představ využili k další vlně germanizace českých zemí. ${ }^{1}$

Nemáme zprávy o tom, zda byl obeznámen s Metternichovými představami o „federalizaci“ habsburské monarchie, jež obsahovala jeho memoranda císaři Františku I., o nichž vedou historici spory, o co v nich vlastně šlo. Z pochopitelných důvodů to nebyl politický systém srovnatelný např. se Spojenými státy americkými. Spíše se zdá, že šlo o taktické vyjádření určitého respektu k multietnictě habsburské monarchie v rámci vnitřní organizace nově uvažovaného ministerstva soudnictví a snahu o vytvoření moderních ministerstev jako takových s jasně vymezenými kompetencemi, pro což však císař, který považoval habsburskou monarchii za „své“ vlastnictví, neměl pochopení. Ostatně

1 Srov. Kutnar, František: Palackého pojeti společnosti, národa a státu. In: Tři studie o Františku Palackém. Usp. F. Kutnar. Olomouc 1949, s. 7-42. Štaif, Jiří: Velká francouzská revoluce v názorech a postojich Františka Palackého a české historiografie jeho doby. In: Napoleonské války a historická pamět. Sborník příspěvků ze stejnojmenné konference konané ve dnech 21.-22. dubna 2005 v Brně. Edd. L. Fasora - J. Hanuš - J. Malír. Brno 2005, s. 83-96. 
Metternichovo memorandum z října 1817 bylo zveřejněno ve Wiener Zeitung v do té míry upravené podobě, jež jeho „federativní“ komponenty zcela potlačila. ${ }^{2}$

Nejvýrazněji ovlivnily po mém soudu Palackého federalismus diskuze o multietnicitě habsburské monarchie, které se odehrávaly v době předbřeznové a do nichž spolu s dalšími českými obrozenci vstupoval i když v nich nebyl na rozdíl od svého př́tele Pavla Josefa Šafaříka jejich hlavním protagonistou. Šafařík r. 1842 publikoval svůj Slovanský národopis, jenž doprovázela mapa nazvaná Slovanský zeměvid. Tím, že zobrazovala též území osídlená neslovanskými národy, podávala širší veřejnosti ucelenou kartografickou reprezentaci multietnicty habsburské monarchie. Šafařík tak téma, které Dobrovský o několik desetiletí dříve řadil do sféry vědeckého bádání, aktualizoval tím, že je posunul do sféry veřejného zájmu, $v$ němž vystupoval do popředí zejména počet př́ślušníků jednotlivých národů a národností a vymezení území, která obývali. Obojí se stávalo předmětem sporů, nebot účastníci diskuse se snažili různými způsoby nadsazovat $\mathrm{z}$ těchto i jiných hledisek význam toho národa, jehož zájem představovali. Počínat si tak mohli mj. proto, že oficiální statistické šetření počtu př́slušníků jednotlivých národů a národností bylo v neuherské části habsburské monarchie provedeno až r. 1846 a pro její uherskou část to bylo ještě o pět let později.

$\mathrm{K}$ tomu připomeňme alespoň to, že Dobrovského př́stup $\mathrm{k}$ věci měl též styčné body s oficiálním rakouským austroslavismem, jenž v období napoleonských válek usiloval o to zmapovat slovanské národy a národnosti, jejichž význam vzhledem k měnícím hranicím státu stoupal z hlediska statistického, resp. demografického, národohospodářského a etnografického. I po napoleonských válkách, když se územní rozsah habsburské monarchie opět stabilizoval, se u rakouských statistiků stále objevovala tendence vnímat tento státní celek také z hlediska jeho multietnicity. Takto chápaný „statistický federalismus“ přihlížel ke skutečnosti, že stát je sice národnostně pestrý, avšak zároveň zdůrazňoval, že tento faktor kulturní rozmanitosti je překlenován vládou habsburské dynastie, v jejímž zájmu je nanejvýš vhodné považovat jednotlivé národnosti podle patriarchálního principu za panovníkovy „děti“. Stejně tak akcentoval skutečnost, že tato etnická rozmanitost je překrývána unitaristickou státní správou, jejímž úkolem je garantovat jednotný výkon státní moci. ${ }^{3}$

Nezůstalo ovšem jen u toho, nebot několik let před revolucí 1848-1849 se začala v politických brožurách, jež vesměs vycházely v Lipsku, kde se jejich autoři nemuseli obávat tuhé cenzury, a v augsburských novinách Allgemeine Zeitung, rozvíjet živá středoevropská diskuze o národnostní otázce v habsburské monarchii. Právě v ní se objevil jeden z nových impulzů v dobových diskursech o moderním národním uvědomění. $\mathrm{V}$ argumentaci jejích účastníků docházelo totiž oproti stoupencům oficiálního „statistického federalismu“ k tomu, že začali chápat jednotlivé národnosti jako kolektivní osoby, jež obývají „svá“ vlastní území, mají své vlastní zájmy, avšak nacházejí se na rozdíné kulturní úrovni,

2 Srov. Sked, Alan: Metternich a Rakousko. Pokus o hodnocení. Brno 2014, s. 121; Siemann, Wolfram: Metternich. Stratege und Visionär. Eine Biografie. München 2016, s. 623.

3 Srov. Štaif, Jiří: Multietnicita a statistika v českých zemích, 1790-1880. In: Sborník k problematice multietnicity. České země jako multietnická společnost. Češi, Němci a Židé ve společenském životě českých zemí 1848-1918. Ed. Z. Kárník. Praha 1996, s. 13-42. 
jež spolu s dalšími faktory jako např. historie, početnost, sociální složení a zejména pak sebevědomí národních elit, vymezují jejich akční rádius. V této souvislosti byl rovněž otevřen problém, zda se ty méně vyspělé mají podřizovat těm vyspělejším, jak se domnívali mluvčí německého a mad’arského národního hnutí, což však představitelé českého národního hnutí rozhodně odmítali. ${ }^{4}$

Nicméně již tehdy bylo zřejmé, že účastníci této diskuze měli z typologického hlediska „na vybranou“, zda příslušná národní hnutí budou vůči habsburskému panovníkovi považovat za nesamostatné děti, jež jsou zcela závislé na svém otci nebo za dospívající děti, na jejichž přání by měl brát již jisté ohledy, či si budou v tomto ohledu počínat ještě samostatněji. V prvním případě stále ještě vycházeli z panovnického patriarchalismu, v druhém se s panovníkem chtěli dělit o vůdčí roli vůči „svým“ národům a ve třetím očekávali jeho respekt k tomu, že se považují za hlavní národní reprezentanty. Představa, že by se jednotlivá národní hnutí zcela vymanila z role panovníkových dětí, nebyla však v této souvislosti akcentována. Tato diskuze pak nepochybně ovlivňovala posuny v názorech i v českém obrozeneckém prostředí. Dva roky před revolucí 1848 se u Karla Havlíčka Borovského setkáváme s austroslavistickým konceptem, v němž jsou jednotlivé slovanské národy a národnosti v habsburské monarchii považovány za do té míry dospělé děti, že již mohou vyjednávat mezi sebou o tom, co je má kulturně a hospodářsky spojovat dohromady. Jeho argumentaci nelze tudíž po mém soudu vysvětlit jen jeho negativními zkušenostmi z předchozího pobytu v Rusku, na jejichž základě odmítl koncepci jednoho slovanského národa. ${ }^{5}$

Mám tím na mysli jeho všeobecně známou novinářskou stat’ Slovan a Čech, kterou zveřejňoval od 15. února do 12. března 1846 v Pražských novinách. Domníval se přitom, že tento austroslavistický projekt je nejen v panovníkově zájmu, o jehož sympatie nepokrytě usiloval, nýbrž že může habsburské monarchii poskytnout také větší míru vnitřní soudržnosti. Tyto názory byly nepochybně blízké i Františku Palackému, jehož lze považovat za protektora Havlíčkovy žurnalistické dráhy. Jejich rámec byl však pouze austroslavistický, nikoliv však austrofederalistický vzhledem k tomu, že úvahy vedené tímto již nezastřeně politickým směrem se zřejmě Havlíčkovi i Palackému nezdály být takříkajíc na „pořadu dne“. Ostatně i kdyby se odhodlali jít tímto směrem, což považuji v této době za velmi nepravděpodobné, pak by se zcela jistě dostali do přímého konfliktu s rakouskou cenzurou, s níž oba získávali nepříjemné zkušenosti. ${ }^{6}$

Stalo se asi jen shodou okolností, že Palacký měl možnost, zdůrazněme přitom pojem možnost, se během svého zimního pobytu v Nice 1844/1845 seznámit s konceptem federalismu francouzského liberálního historika Françoise Guizota. Obsažen byl v jeho

4 Srov. Heidler, Jan: Čechy a Rakousko v politických brožurách předbřeznových. Praha 1920; Sklenář, Karel: Jan Erazim Vocel. Zakladatel české archeologie. Praha 1981, s. 79.

5 K symbolice panovníka jako patriarchálního otce viz alespoň Telesko, Werner: Geschichtsraum Österreich. Die Habsburger und ihre Geschichte in der bildenden Kunst des 19. Jahrhunderts. Wien 2006; Rak, Jiří: Zachovej nám, Hospodine. Češi v Rakouském císařství 1804-1918. Praha 2013.

6 Přetisk Havlíčkovy stati viz: Karla Havlícka Borovského Politické spisy. Díl I. Pražské noviny. (1846-1848). Ed. Z. V. Tobolka. Praha 1900, s. 28-70. Srov. Wögerbauer, Michael - Píša, Petr - Šámal, Petr - Janáček, Pavel a kol.: V obecném zájmu. Cenzura a sociální regulace literatury v moderní české kultuře 1749-2014. Svazek I. 1749-1938. Praha 2015, s. 270, s. 305 aj. 
díle o dějinách evropské civilizace se zvláštním ohledem na Francii, od pádu římské říše až do francouzské revoluce 1789, které vyšlo v Pařiži r. 1828. Palackého v něm nejvíce zajímal výklad vzniku feudalismu. Z hlediska našeho tématu je důležité, že Guizot zde mj. podal výklad o tzv. feudálním federalismu, jímž se šlechta snažila prosazovat své zájmy v rámci mocensky roztř́ššěného lenního systému tím, že dobové problémy řešila na té úrovni, na níž vznikaly. Činila tak zájmovým sdružováním těch, kteří byli ochotni a schopni se jimi zabývat a měli k tomu příslušnou autoritu, resp. byli schopni vykonávat bezprostřední mocenské násilí, jež bylo pole Guizotových představ v raném feudalismu považováno za hlavní záruku práva.

Malá civilizační úroveň této společnosti je však nikterak nenutila k tomu, aby se o svá práva ochotněji dělili s vyššími státními institucemi, jež by oproti jejich partikularismu byly schopny zastávat obecnější zájmy. Guizot přitom moderní politický federalismus vymezoval s odkazem na politické uspořádání Spojených států amerických jako zásadu, podle níž se nižším článkům státního celku ponechává část politické moci, jež je slučitelná s tím, aby federativní stát mohl fungovat jako obecná, resp. ústřední instituce garantující svým občanům ty z politických jistot, jež jim jeho dílčí části nemohly poskytnout, např. stejnou míru práv, povinností a ochrany. Proto k tomu měly mít společné federální orgány dostatečné pravomoci. V zásadě tak chápal moderní federalismus jako optimální vybalancování pravomocí mezi konstitutivními částmi státu a jeho schopností spojovat je ve smysluplný celek. ${ }^{7}$

Nevíme však s jistotou, do jaké míry právě tyto Guizotovy pasáže skutečně ovlivnily Palackého pozdější pojetí federalismu. Jisté je jen to, že mu k tomuto účelu nabízely svůj argumentační potenciál a že úvahy tohoto francouzského historika o evropské civilizaci považoval za natolik důležité, že po revoluci 1848-1849 podporoval svého syna Jana Palackého v tom, aby je přeložil do češtiny. Rovněž tak nemáme zprávy o tom, do jaké hloubky jej zajímal švýcarský federalismus, nicméně však víme, že znal klasické dílo o dějinách švýcarské konfederace od švýcarského historika Johanese Müllera vycházející v letech 1786-1808 jako Geschichte schweizerischer Eidgenossenschaft, jež mu bylo již v jeho mládí důkazem, že i malé národy mohou mít „velké“ dějiny. Dále víme, že byl informován o občanské válce, jež po porážce konzervativních kantonů v listopadu r. 1847 přispěla rozhodujícím zpo̊sobem k dnešní podobě švýcarského státního uspořádání. Tuto historickou událost zároveň považoval za důležitý příznak tlaku na společenské změny v Evropě, k němuž došlo jen několik měsíců před revolucí 1848. O severoamerický federalismus jako model vhodný k napodobení, se, pokud vím, soustavně nezajímal i když o jeho hlavních zásadách byl nepochybně informován. ${ }^{8}$

7 Guizot, François: Cours d'histoire modern. Histoire générale de la civilisation en Europe. Depuis la chute de empire romain jusqu'a la revolution française. Paris 1828, 4. leçon, s. 29-30. Srov. Týž: Dějiny wzdèlanosti v Europě od pádu ř́̌še Řimské až do francauské revoluce. Praha 1851, s. 60-61.

8 Srov. Kořalka, Jiří: František Palacký (1798-1876). Životopis. Praha 1998, s. 46; Briefe an Therese. Korrespondenz von František Palacký mit seiner Braut und späteren Frau aus den Jahren 1826-1860. Hg. J. Kořalka. Dresden 2003, s. 369, 493, 505; Gottlob, Michael: Johannes von Müller (1752-1809). Geschichten schweizerischer Eidgenossenschaft. In: Hauptwerke der Geschichtsschreibung. Hg. R. Volker. Stuttgart 1997, s. $447-450$. 
Byla to až revoluce 1848-1849, která vytvořila potřebný prostor proto, aby se Palacký mohl veřejně profilovat jako ambiciózní architekt ústavní přestavby habsburské monarchie díky tomu, že se ze všech sil snažil propojit český austroslavismus s konceptem austrofederalismu. K tomuto cíli směřovala již jeho programová stat̉ z 11. dubna 1848 O poměru Čech $i$ Rakouska $k$ řřši německé, známá podle svého podtitulu jako Psani do Frankfurtu, jež z něj učinila ve střední Evropě významnou, nicméně však v širším politickém kontextu kontroverzní politickou osobnost. Palacký tehdy spojoval dohromady dva koncepty, jež se ovšem jen z části překrývaly ve svých politických prioritách. Jeho vize zachování a ústavní přestavby habsburské monarchie navíc vstupovala do konkurence s jinými politickými projekty, které s ní však neměly vzájemně slučitelné priority. Již na jaře $r$. 1848 bylo jasné, že se nachází v rozporu s cíli německého, italského, mad’arského a polského národně sjednocovacího hnutí, což z ní činilo vskutku konfliktní téma. Ostatně do jisté míry byla konfliktní i se zájmy některých slovanských národů, jejichž zástupci se sešli ve dnech 2.-12. června 1848 v Praze na Slovanském sjezdu ke společnému rokování. ${ }^{9}$

Potom, co se české politice nepodařilo uskutečnit český ústavodárný sněm, byli její čelní představitelé nuceni vstoupit jako poslanci do vídeňského ústavodárného parlamentu, jehož jednání bylo oficiálně zahájeno 22. července 1848. Teprve tam si začali lépe uvědomovat, jaký má Palackého austroslavistická a austrofederalistická orientace výchozí akční rádius a s kým se dá vyjednávat o její podpoře a s kým ne. $\mathrm{V}$ prvních týdnech zasedání tohoto zastupitelského tělesa byl Palacký v tomto ohledu poměrně optimistický. Hodně si sliboval též od toho, že českou politiku orientoval na vstřícnost $\mathrm{k}$ vídeňské vládě a zejména pak vůči habsburské dynastii. S přibývajícím časem se však poměrně intenzivně vnitřně bránil tomu, aby přijal za svou zkušenost, že parlamentní vliv jeho pojetí austroslavismu a austrofederalismu není tak velký, jak původně očekával. Domníval se přitom, že hlavním nástrojem ústavní přestavby státu by se měl stát jeho návrh nové rakouské ústavy, s jehož prvním náčrtkem byl jako člen ústavního výboru hotov 5 . srpna $1848 .{ }^{10}$

Zdůrazňoval v něm územní integritu habsburské monarchie, přestože ve vídeňském ústavodárném parlamentu nebyly zastoupeny uherské země stejně tak jako Lombardie a Benátsko, jež tvořily habsburské državy v severní Itálii. Z jednotlivých provincií, které byly v parlamentu zastoupeny, vytvářel skupiny zemí polských, českých, německo - rakouských a jihoslovanských, jež měly mít jako základní části budoucí federace společný parlament a ústřední vládu, do jejíž kompetence měly patřit rezorty zahraničních věcí, války, financí, obchodu a veřejných prací a spravedlnosti. Zvlášt mu záleželo na tom, aby v budoucí ústavě bylo zakotveno spojení českých zemí v jeden státoprávní celek, ačkoliv dobře věděl, že tento požadavek je nepřijatelný jak pro demokraticky orientované české Němce, tak pro moravskou a slezskou politickou zemskou reprezentaci. Nicméně se

9 Přetisk Palackého stati: Františka Palackého Spisy drobné. Díl I. Spisy a řeči z oboru politiky. Usp. B. Rieger. Praha 1898, s. 16-22; dále srov. Kořalka, J.: František Palacký, s. 265.

10 Přetisk tohoto dokumentu: České a československé dějiny III. Dokumenty a materiály. Ed. J. Harna. Praha 1992, s. 82-83. Při výkladu Palackého působení v rakouském ústavodárném parlamentu v letech 18481849 se opírám o Kořalka, J.: František Palacký, s. 293-318 a Štaif, Jiř́i: František Palacký. Život, dílo, mýtus. Praha 2009, s. 166-194. 
domníval, že našel schůdnou cestu k tomu, jak vybalancovat princip centralismu s principem federalismu, což byl ovšem názor, jenž nesdílela řada jeho parlamentních kolegů.

Svioj návrh potom rozpracoval do 72 paragrafů v průběhu září 1848, v nichž argumentoval ve stejném duchu. ${ }^{11} \mathrm{Z}$ federalistického hlediska zdůrazňoval na úkor centralismu zejména to, že poslanci ústředního parlamentu mohou být voleni jen ze středu poslanců zemských sněmů, které mohly v některých případech omezovat či dokonce rušit celoříšské zákonodárství. Na druhé straně přisuzoval důležitou integrační roli panovníkovi, který mohl pozastavit schválení jakéhokoliv parlamentního zákona minimálně na dva roky. Tento elaborát Františka Palackého již nemohl být projednáván, protože ve Vídni došlo v ř́innu 1848 k revoluci. Po její porážce byl tento zastupitelský orgán okolnostmi přinucen přestěhovat se do Kroměříže, kde zahájil své jednání 22. listopadu 1848. Od začátku r. 1849 se nad ním navíc snášela hrozba jeho rozpuštění ze strany nové vlády knížete Felixe Schwarzenberga, která cílevědomě sledovala linii směřující ke stabilizaci revolucí rozjitřených společenských poměrů. V této atmosféře časového tlaku se parlamentní ústavní výbor začal intenzivněji věnovat rokování nad textem budoucí ústavy.

V Kroměříži došlo ovšem ke sblížení parlamentního centra s parlamentní levicí, což se projevilo v ústavním výboru tím, že Palackého pojetí ústavy v něm nemohlo získat potřebnou podporu. Tato změna koaliční potenciál jeho ústavních zásad z pochopitelných důvodů ještě více omezovala. Ani na pěstování dobrých vztahů vůči vládě a habsburské dynastii již nemohl sázet tak, jako tomu bylo dříve ve Vídni, nebot’ vstřícné kroky české politiky již k ničemu nepotřebovaly. Navíc prováděly již do té míry otevřenou protirevoluční politiku, že i u austrofilského Palackého vyvolávaly stále větší obavy, že směřují $\mathrm{k}$ otevřené vojenské diktatuře. Většinovou podporu si v kroměřížském ústavním výboru získal ústavní návrh centristy, moravského Němce Kajetana Mayera, jenž byl postaven na konceptu tzv. federativního centralismu. Podle něj měly být jednotlivé země ovšem jen nevýraznými komponentami státu vzhledem k tomu, že pravomoci jednotlivých zemských sněmů byly omezovány nejen shora ústředním parlamentem, nýbrž i zdola sněmy jednotlivých krajů, které měly být vytvořeny tak, aby byly národnostně co nejsourodější. Během projednávání v ústavním výboru byly centralistické prvky Mayerova návrhu ještě o něco posilovány na úkor těch federativních. Palackému se v tomto orgánu nepodařilo prosadit ani návrh, aby se budoucí ústava týkala celé monarchie a aby v ní byly dílčí státní celky vytvořeny podle etnických hranic bez ohledu na hranice jednotlivých zemí. ${ }^{12}$

Na znění nové rakouské ústavy se ústavní výbor dohodl 2. března 1849. Stalo se tak k velké nelibosti Palackého, který doufal, že by do její konečné podoby mohl ještě účinně zasáhnout v parlamentním plénu. K tomu však nedošlo, nebot 7. března 1849 byl parlament rozpuštěn a zároveň vydána Stadionova oktrojovaná ústava. Palacký měl jako upřímný federalista pocit velké osobní křivdy a zneuznání veškeré práce, kterou do promýšlení a sepisování svých ústavních návrhů vložil. Nicméně i potom považoval svůj austrofederalismus za nejlepší způsob, jak dosáhnout vyrovnání zájmů všech národů

11 Přetisk: Františka Palackého Spisy drobné. Díl I., s. 57-64.

12 Srov. Přetisk Mayerova ústavního návrhu: Gottsmann, Andreas: Der Reichstag von Kremsier und die Regierung Schwarzenberg. Die Verfassungsdiskussion des Jahres 1848 im Spannungsfeld zwischen Reaktion und nationaler Frage. Wien 1995, s. 122-133. 
a národností v habsburské monarchii co nejspravedlivějším způsobem. Přitom však neustále narážel na problém, že ani v nové ústavní éře nenacházely jeho politické vize takovou politickou podporu, aby je byl schopen alespoň do jisté míry prosadit. $\mathrm{V}$ tomto směru viděl chybu vždy na té druhé straně, nebot’ se domníval, že jeho přístup k problematice vzájemného soužití různých národů v jednom státu je nanejvýše etický.

Palackého pozice v rakouské politice byla tehdy ovšem slabší než v letech 1848-1849. I jeho představy o austrofederalismu se proměňovaly pod tlakem měnících se politických okolností, jež nebyly pro českou politickou reprezentaci příliš příznivé. Nicméně se jimi stále snažil ovlivňovat širší veřejnost. Nejnápadněji se tak projevil ve svých politických úvahách na téma Idea státu rakouského (1865), kde se nechal inspirovat uherským státním právem. Přál si přitom, aby česká politika byla ve spojení s českou konzervativní šlechtou schopna prosazovat koncept českého státního práva s takovou rozhodností, s níž by si vynutila stejný respekt ve vídeňských vládních a dvorských kruzích jako uherská politická reprezentace, v čemž se ovšem přepočítal. Jeho představa o zastupitelských a správních orgánech zreformované habsburské monarchie byla navíc natolik komplikovaná, že by v politické praxi nemohla vůbec fungovat. Zároveň se pokoušel o politický nátlak, resp. vyslovil hrozbu v tom smyslu, že ztroskotání snah o federalizaci habsburské monarchie, s sebou přinese vzrůst vlivu politického panslavismu, jenž nakonec způsobí její zánik. ${ }^{13}$

Ani v tomto případě se mu však nepodařilo vydobýt si vůči svému federalismu takový respekt, aby jej byl schopen třeba jen v kompromisní podobě prosadit. Navíc bylo stále zřejmější, že řízení politických záležitostí přenechává svému zeti Františku Ladislavu Riegerovi s tím, že je chce ovlivňovat z pozadí a přímo bude na toto pole vstupovat jen tehdy, když to uzná za vhodné. I v následujících létech se potvrdilo, že česká politika neměla dost sil k tomu, aby uskutečnila Palackým projektované federalistické cíle. Začala je proto po jeho smrti sice nenápadně, nicméně však krok za krokem opouštět, nebot' alternativní řešení vưči dualistickému uspořádání habsburské monarchie (1867) nebyla schopna prostě prosadit. Nepodařilo se jí to ani po vydání „trialistické“ státoprávní deklarace (1868), ani po vyjednávání s předlitavskou vládou o tzv. fundamentálních článcích (1871), jejichž cílem bylo zajistit zvláštní státoprávní postavení českých zemích v rámci Předlitavska. Přípravných jednání o jejich podobě se však Palacký již nezúčastnil. K tomu dodejme, že až do počátku první světové války si česká politika nezískala ani potřebnou zahraničně - politickou podporu, s níž Rieger na konci 60. let 19. století i později marně počítal ze strany Francie a Ruska. ${ }^{14}$

Pokusme se tedy o shrnutí předchozího výkladu. Federalismus v programových politických stanoviscích Františka Palackého lze hodnotit z protikladných úhlo̊ pohledu. Na jedné straně můžeme zdůrazňovat, že jeho osobnost měla rozměr politického proroka, který pochopil, že habsburská monarchie se musí rozpadnout, pokud její vládnoucí

13 Přetisk stati: Františka Palackého Spisy drobné. Díl I., s. 209-267. K tomu srov. alespoň Štaif, J.: František Palacký, s. 250.

14 Srov. alespoň Urban, Otto: Česká společnost 1848-1918. Praha 1982, s. 238, s. 248; Pfaff, Ivan: Francie a Čechy v Europě národnich států. Francouzská politika F. L. Riegra 1867-1878. Praha 2013; Štaif, Jiř́í: Palacký, Rieger a Rusko 1848-1898. Identita, zkušenost a geopolitika. In: J. Hanuš a kol.: Rusko a Západ. Eseje o (ne)porozumění. Brno 2015, s. 105-130. 
kruhy připustí, aby v ní jedny národy ovládaly jiné. Na druhé straně v něm lze rovněž vidět nacionalistického zatvrzelce, jenž v multietnickém prostředí tohoto státu „přespř́í liš“ zdůrazňoval české národní cíle, a to zvlášṫ ve vztahu k Němcům v českých zemích. Nazírat jej lze dokonce jako politického pošetilce, který se svou podporou územní celistvosti habsburské monarchie a svým austrofederalismem a austroslavismem postavil v revoluci 1848-1849 trestuhodně do cesty obecnému historickému pokroku.

Nehledě k těmto názorům si však zkusme připustit, že se snažil hledat odpověd' na problém, na jehož řešení lze sotva nalézt nějaký univerzální recept. Zároveň však dost dobře nepochopil, že i ty nejušlechtilejší vize se nemohou v moderní době stát alespoň do jisté míry historickou skutečností, pokud si nezískají tak velké či vlivné množství př́ivrženců, kteří je budou schopni uskutečňovat. Zjištění, že se to Františku Palackému jako mnoha dalším politickým vizionářům nepodařilo, však po mém soudu neznamená, že bychom měli jako historici tyto typy politiků a jejich cíle odbýt jen mávnutím ruky nebo se o ně již vůbec nezajímat. Spíše bychom si měli položit otázku, zda nás svým pohledem na veřejné záležitosti zavádějí, zda nás něčím činí ostražitými a zda nás mohou ještě něčím inspirovat.

Palackého austrofederlismus nepovažuji v této souvislosti za zavádějící, či jinak scestný politický koncept, ačkoliv se týkal několika národů, které měly ambici vytvořit vlastní národní stát. $Z$ tohoto důvodu $\mathrm{k}$ němu byli jejich představitelé nedůvěriví a nezř́ídka i nepřátelští, což byl nepochybně jeden z hlavních důvodů jeho omezeného koaličního potenciálu. Za další z nich je možné považovat skutečnost, že české národní hnutí nemělo dost sil na to, aby se stalo v habsburské monarchii směrodatným politickým činitelem, což je ovšem zřejmější z časového odstupu, než to bylo v letech 1848-1849 a 1866-1867, v nichž bylo možno prosadit dlouhodobější historickou změnu. Současný historik by však neměl př́liš nadužívat výhody svého časového odstupu k tomu, aby řešil problém, zda to měly osobnosti typu Františka Palackého „včas“ rozpoznat. Ostražitý by však měl být tehdy, když se hlouběji zamyslí nad tím, zda by jeho austrofederalistické návrhy prakticky dobře fungovaly, pokud by si získaly dostatečnou podporu ke svému uskutečnění. $\mathrm{V}$ tomto př́ípadě si však nejsem jist úplně tím, že by tomu tak skutečně bylo. Inspirativní pro nás však může být Palackého vize, jejímž cílem bylo hledat upřímně a zároveň i s velkým vnitřním nasazením vhodné cesty k perspektivnímu soužití různých národů a národnostî v multietnickém státu. 


\section{Palacký's federalism and its potential for coalitions}

The author firstly examines what influenced or could have influenced the federalist ideas of the leading representative of the Czech national movement, František Palacký (1798-1876). In the pre-March period this came mainly from statistical data on the population numbers of the individual nations and nationalities within the Habsburg monarchy and the cartographical representations of the territories they inhabited. Added to this was the concept of Austro-Slavism, which emphasized the cultural, demographic and economic importance of Slavs living in this state. In the revolution of 1848-1849 he linked this to an Austro-federalism, which he saw as being the best guarantee for the equal status of all the nations and nationalities within the Habsburg monarchy. He presented his constitutional proposals to the Austrian Constitutional Parliament, though he failed to acquire sufficient support because their potential for coalitions was limited by a number of factors. After the renewal of constitutional life in the Habsburg monarchy it became clear that the chances of Palackýs ideas of Austro-federalism being a success had not improved since the revolution of 1848-1849. This was because the Czech politician had been unable to make any allies either within the internal political scene or abroad (France and Russia), who would support him in promoting his objectives. For this reason, following Palackýs death there was a gradual retreat from his Austro-federalism. However, his political vision of attempting to find a solution to the coexistence of the various nations and nationalities within a multi-ethnic state was commended. 